\title{
UNDERSTANDING POETRY THROUGH THE USE OF COOPERATIVE LEARNING MODEL
}

\author{
Dina Ramadhanti', Diyan Permata Yanda ${ }^{2}$ \\ STKIP PGRI Sumatera Barat \\ e-mail: dina@stkip-pgri-sumbar.ac.id ${ }^{1}$,diyan@stkip-pgri-sumbar.ac.id ${ }^{2}$
}

\begin{abstract}
This study describes the learning process of inner and physical structure of poetry understanding through the use of Student Team Achievement and Division (STAD) and Cooperative Integrated Reading and Composition (CIRC) cooperative learning models. In addition to the cooperative learning models, literary reading interest is also used as a consideration in the learning process of poetry understanding. This experimental study involved 63 samples from a total of 124 people. Samples were randomly selected and assigned into two experimental groups. The experimental group I, with a total of 33 subjects, was treated with the STAD model, while the experimental group II, with a total of 30 subjects, was treated with the CIRC model. The subjects in the two experimental groups were assigned to complete a literary reading interest questionnaire. After the treatment, a poetry understanding test was given to the subjects in the two groups. A $t$-test was subsequently used to examine the students learning outcome, by considering their interest in literary reading. The results of data analysis showed no significant differences in the application of cooperative learning models in poetry understanding. Both students with high and low literary reading interest found the learning models helpful in improving their performance in the understanding inner and physical structure of poetry. Students with low literary reading interest were motivated in the learning process as a result of the teamwork in completing the poetry understanding tasks.
\end{abstract}

Keywords: poetry understanding, cooperative learning, literary reading interest

\section{PEMAHAMAN PUISI MENGGUNAKAN MODEL PEMBELAJARAN KOOPERATIF}

Abstrak: Penelitian ini mendeskripsikan proses pembelajaran memahami struktur batin dan struktur fisik puisi menggunakan model pembelajaran kooperatif tipe Student Team Achievement and Division (STAD) dan Cooperative Integrated Reading and Composition (CIRC). Selain menerapkan model pembelajaran kooperatif, minat baca sastra juga menjadi pertimbangan dalam proses pembelajaran memahami puisi. Penelitian eksperimen ini dilakukan pada 63 orang sampel dari 124 orang populasi. Sampel dipilih secara acak dan ditugaskan ke dalam dua kelompok eksperimen. Kelompok eksperimen I dengan jumlah partisipan 33 orang diberikan perlakuan dengan model STAD dan kelompok eksperimen II dengan jumlah partisipan 30 orang diberikan perlakuan dengan model CIRC. Sampel pada kedua kelompok eksperimen diminta untuk mengisi angket minat baca sastra. Setelah diberikan perlakuan, sampel pada kedua kelompok eksperimen mengerjakan tes pilihan ganda memahami puisi. Hasil belajar kedua kelompok dengan menggunakan uji t-test dibandingkan dengan pertimbangan minat baca sastra. Hasil analisis data menunjukkan tidak terdapat perbedaan yang signifikan dari penerapan model pembelajaran kooperatif dalam proses memahami puisi. Model pembelajaran yang digunakan dapat membantu meningkatkan kinerja siswa dalam memahami struktur batin dan struktur fisik puisi, baik mahasiswa dengan minat baca sastra tinggi maupun mahasiswa dengan minat baca rendah. Mahasiswa yang memiliki minat baca sastra rendah termotivasi dalam proses pembelajaran karena adanya kerjasama tim dalam menyelesaikan tugas-tugas belajar memahami puisi.

Kata Kunci: pemahaman puisi, pembelajaran kooperatif, minat baca sastra

\section{INTRODUCTION}

High-level thinking processes, communication skills, and social relationships
(Bromley \& Modlo, 1997) are an important issue and become the capital to build a better life in the 21 st century. Cooperative learning 
becomes the solution used in the learning process in accordance with the demands of the century 21. Cooperative learning is a group learning that gives students more responsibility for their own learning and teams resulting in an interdependence relationship that promotes positive social relationships in the classroom and builds a classroom climate that aids in the learning process (Stevens, 2008:105). Cooperative learning can improve learning achievement (Tiantong \& Teemuangsai, 2013); (Durukan, 2011); (Adesoji \& Ibraheem, 2009) through the interaction of the social environment and change the objective structure in the classroom to focus on improving learning outcomes and positive motivation for all students.

Children view cooperative learning as a way to help them become more successful, especially in order to prepare for social life by building collaboration and collectivity. Cooperative learning has an effect on the relationships among students in groups, mutual acceptance, and improvement of students' selfesteem. In other words, cooperative learning will help students improve literacy skills, improve metacognitive strategies for thinking and learning awareness, build effective communication skills, improve language skills, and improve social skills (Bromley \& Modlo, 1997). In addition, the more students work together in collaborative groups, the more they understand, retain, and feel better about themselves and their peers on the team. Collaborative group collaboration encourages student responsibility to improve learning achievement and social skills (Tiantong \& Teemuangsai, 2013).

The Student Team Achievement Team and Division (STAD) model is a model of cooperative learning that can help develop students' positive attitudes toward themselves, peers, adults, and learning in general (Adesoji \& Ibraheem, 2009). STAD is conducted with the teacher presenting the subject matter, the students in the heterogeneous group are involved cooperatively according to the material being studied, the teacher gives the question according to the subject matter to the student in the form of quiz, the students answer the question individually without help from their teammate, each team member is calculated to find the team score, the teacher rewards the best three teams (Slavin, 1994); (Adesoji \& Ibraheem, 2009), (Tiantong \& Teemuangsai, 2013).
The Cooperative Integrated Reading and Composition (CIRC) model is also a cooperative learning model based on teamwork designed to develop reading and writing skills. CIRC is implemented with students prepared in heterogeneous reading groups, students are paired in reading groups by conducting feedback learning to develop basic skills, such of oral reading, contextual guessing, asking questions, summarizing, and composing writing, then assessing (Slavin, 1994). The CIRC model can improve the achievement and retention of reading and writing (Durukan, 2011).

Cooperative learning model types of STAD and CIRC is applied in language classes for learning to understand poetry. This learning model is used as a way of overcoming gaps between poetry learning with the demands of learning that should be, such as: the capital of poetry learning competencies, packaging of poetry learning goals, packaging of poetry learning, packaging methods and strategies for poetry learning, packaging of poetry learning media, and packaging learning evaluation (Suyitno, Andayani, \& Nugraheni, 2015).

Cooperative learning in language classes can have a positive effect on student learning outcomes, a key factor affecting student feedback in the learning process, and making students comfortable in learning, freer in the classroom, motivated, and more active in communicating, which is high for learning (Sachs, Shum, Bureau, Kong, \& Christopher, 2003). For learning to understand poetry, students are required to understand the physical structure and inner structures of poetry. The inner structure consists of a theme, feeling, tone, and intention. The inner structure consists of typography, imagery, concrete words, figurative language, and verification (Ramadhanti \& Diyan, 2017). The theme is the subject of a poem. The Feeling is the poet's appreciation, attitude, or emotion for the subject of the poem he wrote, such as a feeling of wonder, sadness, joy, anger, surprise, joy, disbelief, counsel, and so on. Tone refers to the poet's attitude to the issues discussed in his work, such as patronizing, berating, wooing, whining, inviting, sarcastic, and so on. The Intention is a message the poet wants to convey, for example expecting the reader to be angry, hateful, like something, and rebel against something. Typography is the appearance of a 
poem as one of the creative arts. The appearance of the poem can be observed in various forms, such as language structuring, the use of signs or symbols, setting the spacing of lines, setting letters, words, lines, or stanzas. Imagery is a word or composition of words that can express one's sensory experiences, such as the image of a vision, hearing, smell, and feeling. A concrete word is a word that a poet explicitly uses in conveying the issues he conveys. These concrete words are the words that the senses can sense to allow for the appearance of images. Figurative language is a language full of allegories, such languages can turn on, alert effects, and cause certain connotations. Verification concerns the issue of rhyme and rhythm

The implementation of cooperative learning in the classroom is influenced by certain variables, such as gender, level of proficiency, time, patterns of class interaction, and attitudes toward others. In addition, interest in literary reading is also a variable that also influences the learning process. Furthermore, the interest in reading someone is known through three aspects, namely attention, feelings and responses to what is read. Attention includes the frequency, amount, and time spent in reading. Feelings include a feeling of joy to the reading material and the interest and satisfaction after reading. Responses include reading comprehension, finding problems and taking solutions, and benefiting after reading (Slameto, 2010). Students need a high reading interest because reading skills are very important to improve the success of students in school and outside the school, while students who have low reading interests will have difficulty motivating themselves to read for academic purposes, what else for fun (Khairuddin, 2013). Social skills created through cooperative learning will help students improve vocabulary and reading skills (Shaaban, Al-Badawi, \& Ghaith, 2007). Thus, students with low reading interests will be motivated in the learning process.

The research was conducted to prove the hypothesis about the influence of cooperative learning model in learning to understand poetry by considering literary reading interest, both high and low. Hypothesis tested, namely: there is a significant difference between the results of learning to understand the poetry of students who have high literary reading interest in learning with cooperative learning model type STAD and
CIRC, there is a significant difference between the results of learning to understand poetry students who have low literary reading interest in learning with STAD and CIRC cooperative learning model, and there is interaction between the use of cooperative learning model and literary reading interest in influencing the learning result of understanding poetry.

\section{METHOD}

This study uses experimental research design. Participants in this study were students who studied is the Indonesian language and literature education courses STKIP PGRI West Sumatra. Participants are male and female students who take the Poetry Appreciation course. This course is studied in the third semester during their studies. Initial tests were given to 124 students to determine the homogenization of study participants. Then 63 of the 124 participants with a score of one standard deviation above and below the mean were randomly assigned to two experimental groups, 33 participants in the experimental class I and 30 participants in the experimental class II.

The following instruments were used as data collection tools in this study: literary reading interest questionnaire and multiple choice test questions.

\section{Literary Reading Interest Questionnaire}

Literary reading interest questionnaire is structured according to the three main aspects of reading interest, namely: attention to reading, feelings of reading, response after reading. The questionnaire consisting of 70 items statement. Prior to use in the study, each item of the questionnaire was given to the expert to be validated.

The multiple choice test is structured according to the physical structure and inner structure of the poem consisting of 50 items of an item. Prior to use in the study, expert validation for each item was tested and tested to determine the validity and reliability of the test.

To facilitate the treatment process with STAD and CIRC model prepared by the lecture unit which contains steps of applying STAD and CIRC model in the learning process to understand poetry. To make it easier for participants to understand poetry, they are given the book "Understanding Poetry." The book contains 
poetry recognition materials, understanding the elements of form and content of poetry, understanding the elements of sound in poetry, understanding the elements of language in poetry, understanding the elements of imagery in poetry, understanding aspects of figurative language in poetry (Ramadhanti \& Diyan, 2017)

\section{Procedure}

Samples in both experiment classes fill out a literary reading interest questionnaire for high literary reading interest and low literary reading interest.

In the experimental class I, implemented learning by applying STAD type cooperative learningmodel.STAD is implementedbyapplying five main components: class presentations, group work, quiz assignments, individual progress scores, and team recognition.

Class presentation: The class presentation is led by the teacher. The issues discussed are subject matter activities during STAD implementation. This activity makes it easier for participants to do quizzes, quiz score scores, and their team scores. (a) Group work: group work is carried out to prepare each individual in the quiz work. The material understands poetry and analyzes understanding the inner structure and physical structure of poetry understood in group work. They work together so that each individual understands the subject matter. (b) Quiz giving: the teacher presents additional material related to understanding poetry, then the participants working on the individual quiz understand the poetry. (c) Individual progress score: each participant earns an initial score based on the results of the quiz. The participants then collected points for their team based on the level of quiz score increase compared to their initial score. (d) Group recognition: teams will be rewarded if their score reaches certain criteria related to the purpose of learning to understand poetry.

In the experimental class II, learning is done by applying the cooperative learning model of CIRC type. CIRC is implemented by applying three main components, namely: basic activities related to cooperative learning, reading comprehension, and integrated writing activities. (a) Basic activities related to cooperative learning: basic activities undertaken are group divisions and the provision of materials and poems for analysis of poetical understanding in the learning process. Participants work in pairs in groups. (b) Understanding the reading: Participants are given a given poem, identifying key ideas related to the inner structure and physical structure of poetry, understanding the relationships between elements in the poem, and making conclusions about the inner structure and physical structure of poetry. (c) Integrated writing activity: Participants write out the results of an understanding of the inner structure and structure of poetry in the form of a short essay. The essay contains an explanation of the meaning contained in the poem.

The test of understanding poetry in the form of multiple choice tests is given after the treatment with STAD and CIRC models is carried out in the experimental class.

\section{Data Analysis}

To test the hypothesis of the difference of learning result to understand poetry (hypothesis 1 and hypothesis 2) is done by using t-test and for the third hypothesis test which aims to know the interaction of using cooperative learning model type STAD and CIRC and literary reading interest to result learn to understand poetry used formula a unweighted means method (Ferguson, 1976: 258-260).

\section{RESULTS AND DISCUSSION \\ Result}

\section{Analysis of Questionnaire on Student Literary Reading Interest}

The results of the measurement of literary reading interest show that students have the high and the low literary reading interest. Of the 63 students obtained information as many as 34 students have high literary reading interest and 29 students have low literary reading interest. Students who have high and low literary reading interest are scattered in the experimental class I and in the experimental class II. Measurement of literary reading interest includes three aspects, namely: attention, feeling, and response to the reading material.

\section{Attention to the Reading Material}

Attention to the reading material reviewed in terms of three indicators, namely: frequency of reading literary works, time used, and the number of literary works reads. Reviewed from 
the frequency of reading literary works, student responses are presented in table 1 below.

\section{Table 1. Students Responses to the Frequency} of Reading Literary Works

\begin{tabular}{llc}
\hline \multicolumn{1}{c}{ Item } & \% \\
\hline 1 & $\begin{array}{l}\text { I took the time to read literary works } \\
\text { when on holiday }\end{array}$ & 66,0 \\
7 & $\begin{array}{l}\text { I took the time to read even though I was } \\
\text { tired of all the routines }\end{array}$ & 55,9 \\
3 & $\begin{array}{l}\text { Reading literary works becomes an } \\
\text { option when I feel bored reading other } \\
\text { books. }\end{array}$ & 70,2 \\
2 & $\begin{array}{l}\text { I like learning related to literary works } \\
\text { because I like reading literary works. }\end{array}$ & 76,8 \\
6 & $\begin{array}{l}\text { By reading literary works, I can follow } \\
\text { the learning process well. }\end{array}$ & 81,3 \\
5 & $\begin{array}{l}\text { I often borrow books related to literary } \\
\text { works when visiting the library. }\end{array}$ & 66,0 \\
4 & $\begin{array}{l}\text { The learning task that I did first was that } \\
\text { which was related to literary works. }\end{array}$ & 64,8 \\
\hline & $\quad$
\end{tabular}

Reviewed from the time used to read literary works, student responses are presented in table 2 below.

Table 2. Students Responses to the Time Spent Reading Literary Works

\begin{tabular}{clc}
\hline \multicolumn{1}{c}{ Item } & \% \\
\hline 8 & $\begin{array}{l}\text { I usually visit the reading room or } \\
\text { library to read literary works. }\end{array}$ & 67,3 \\
10 & $\begin{array}{l}\text { I read literary works to fill my spare } \\
\text { time. }\end{array}$ & 64,8 \\
13 & $\begin{array}{l}\text { I read a book every day before starting } \\
\text { the activity. }\end{array}$ & 67,9 \\
11 & $\begin{array}{l}\text { I usually read at least 30 minutes every } \\
\text { day. }\end{array}$ & 57,5 \\
9 & $\begin{array}{l}\text { I usually read a maximum of 1 hour } \\
\text { every day. }\end{array}$ & 57,1 \\
12 & $\begin{array}{l}\text { To motivate myself to read diligently, I } \\
\text { put motivational sentences in my room. }\end{array}$ & 80,9 \\
\hline
\end{tabular}

Reviewed from the number of literary works that are read, students responses are presented in table 3 below.
Table 3. Students responses to the number of literary works read

\begin{tabular}{llc}
\hline \multicolumn{1}{c}{ Item } & \% \\
\hline 14 & $\begin{array}{l}\text { I target at least reading one literary work } \\
\text { every day. }\end{array}$ & 68,9 \\
15 & $\begin{array}{l}\text { My goal of reading literary works is to add } \\
\text { insight. }\end{array}$ & 73,3 \\
16 & I have an interest in reading literary works. & 74,6 \\
17 & I have read at least 7 recent literary works. & 58,4 \\
18 & $\begin{array}{l}\text { I read literary works because I wanted to be a } \\
\text { writer of literary works. }\end{array}$ & 70,2 \\
19 & $\begin{array}{l}\text { I tried to find the creative process of the } \\
\text { writers in writing literary works. }\end{array}$ & 69,5 \\
\hline
\end{tabular}

\section{Feelings to the Reading Material}

Feelings to the reading material reviewed in terms of two indicators, namely: feelings of pleasure towards literary reading material and interest or satisfaction after reading literary works. Reviewed by the feeling of pleasure in reading literary works, students responses are presented in table 4 below.

Table 4. Students Responses to Feelings of Pleasure Towards Literary Works

\begin{tabular}{|c|c|c|}
\hline & Item & $\%$ \\
\hline 20 & $\begin{array}{l}\text { I read literary works because I want to be a } \\
\text { writer. }\end{array}$ & 75,9 \\
\hline 21 & $\begin{array}{l}\text { The books that I read more about literary } \\
\text { works. }\end{array}$ & 75,2 \\
\hline 22 & I feel satisfaction after reading literary works. & 82,2 \\
\hline 32 & $\begin{array}{l}\text { I feel there is something missing if I haven't } \\
\text { read literary works. }\end{array}$ & 62,2 \\
\hline 28 & I feel bored if I don't read. & 75,2 \\
\hline 29 & $\begin{array}{l}\text { I feel comfortable after reading literary } \\
\text { works. }\end{array}$ & 65,7 \\
\hline 30 & $\begin{array}{l}\text { I feel relaxed after reading even in the midst } \\
\text { of busy activities. }\end{array}$ & 70,2 \\
\hline 23 & $\begin{array}{l}\text { I feel satisfied every time I finish reading } \\
\text { literary works. }\end{array}$ & 65,1 \\
\hline 25 & $\begin{array}{l}\text { I choose to read rather than do anything else } \\
\text { in my spare time. }\end{array}$ & 64,1 \\
\hline 27 & I read a book before the learning began. & 82,5 \\
\hline 26 & $\begin{array}{l}\text { The reading that I read really helped me in } \\
\text { the learning process. }\end{array}$ & 73,3 \\
\hline 31 & $\begin{array}{l}\text { I always take time to read literary works } \\
\text { every day despite many activities. }\end{array}$ & 62,2 \\
\hline
\end{tabular}

Reviewed by the interest and satisfaction after reading literature, students responses are presented in table 5 below. 
Table 5. Students Responses to Interest/ Satisfaction After Reading Literary Works

\begin{tabular}{llc}
\hline \multicolumn{1}{c}{ Item } & \multicolumn{1}{c}{$\%$} \\
\hline 37 & $\begin{array}{l}\text { I always read attentively and } \\
\text { concentration. }\end{array}$ & 77,1 \\
34 & $\begin{array}{l}\text { I read to easily answer questions. } \\
33\end{array}$ & $\begin{array}{l}\text { I read to make it easy to explain the } \\
\text { contents of the reading to friends. }\end{array}$ \\
36 & $\begin{array}{l}\text { I got ease in learning because I read a } \\
\text { lot. }\end{array}$ & 74,3 \\
42 & $\begin{array}{l}\text { I prefer reading instead of doing others. } \\
41\end{array}$ & $\begin{array}{l}\text { I have a great interest in reading literary } \\
\text { works. }\end{array}$ \\
40 & $\begin{array}{l}\text { I am more interested in reading literary } \\
\text { works more than reading other books. }\end{array}$ & 76,8 \\
43 & $\begin{array}{l}\text { I have my own satisfaction after reading } \\
\text { literary works. }\end{array}$ & 70,5 \\
35 & $\begin{array}{l}\text { I have a large collection of books on } \\
\text { literary works. }\end{array}$ & 57,5 \\
39 & $\begin{array}{l}\text { I always visit the book bazaar to buy the } \\
\text { latest books. }\end{array}$ & 54,3 \\
38 & I bought a book and hastened to read it. & 63,8 \\
\hline
\end{tabular}

\section{Response to the Reading Material}

Response to the reading reviewed in terms of three indicators, namely: understanding literary content, finding problems and problemsolving solutions in literary works, and taking advantage after reading literary works. Reviewed from understanding the contents of literary works, students responses are presented in table 6 below.

Table 6. Students ResponsesinUnderstanding the Contents of The Literary Works

\begin{tabular}{llc}
\hline \multicolumn{1}{c}{ Item } & \multicolumn{1}{c}{$\%$} \\
\hline 49 & $\begin{array}{l}\text { I can understand the contents of literary } \\
\text { works. }\end{array}$ & 69,5 \\
46 & $\begin{array}{l}\text { I can explain again the contents of the } \\
\text { literary works. }\end{array}$ & 75,6 \\
47 & $\begin{array}{l}\text { I try to understand literary works to get } \\
\text { the values contained in them. }\end{array}$ & 75,6 \\
50 & $\begin{array}{l}\text { I understand the meaning of every word } \\
\text { conveyed in a literary work. }\end{array}$ & 78,1 \\
44 & $\begin{array}{l}\text { During the learning, I was asked by the } \\
\text { lecturer to answer questions according to } \\
\text { the contents of the reading. }\end{array}$ & 75,6 \\
45 & $\begin{array}{l}\text { I can help friends who have difficulty } \\
\text { understanding literary works. }\end{array}$ & 70,8 \\
48 & $\begin{array}{l}\text { I can quote every message conveyed } \\
\text { through the literary work that I read. }\end{array}$ & 74,3 \\
\hline
\end{tabular}

Reviewed from the way of finding problems and problem-solving solutions in literary works, students responses are presented in table 7 below.

\section{Tabel 7. Students Responses to Feeling Happy With Literary Works}

\begin{tabular}{llc}
\hline \multicolumn{1}{c}{ Item } & \% \\
\hline 51 & $\begin{array}{l}\text { I always record the important things that } \\
\text { I found during reading. }\end{array}$ & 78,4 \\
52 & $\begin{array}{l}\text { After reading literary works, I gained a } \\
\text { lot of experience. }\end{array}$ & 79,4 \\
54 & $\begin{array}{l}\text { I have benefited a lot after reading } \\
\text { literary works. }\end{array}$ & 77,8 \\
56 & $\begin{array}{l}\text { I found various portraits of everyday life } \\
\text { in literary works. }\end{array}$ & 79,4 \\
53 & $\begin{array}{l}\text { With a lot of reading literary works, I } \\
\text { love the environment more. }\end{array}$ & 73,3 \\
55 & $\begin{array}{l}\text { I can apply values in literary works in } \\
\text { everyday life. }\end{array}$ & 68,9 \\
\hline
\end{tabular}

Reviewed of the benefits obtained after reading literary works, students responses are presented in table 8 below.

Tabel 8. Students Responses to Benefits After Reading Literary Works

\begin{tabular}{llc}
\hline \multicolumn{1}{c}{ Item } & \% \\
\hline 59 & $\begin{array}{l}\text { I have benefited a lot after reading } \\
\text { literary works. }\end{array}$ & 77,8 \\
57 & $\begin{array}{l}\text { I get various life values in literary } \\
\text { works. }\end{array}$ & 67,6 \\
58 & $\begin{array}{l}\text { I get a new experience after reading } \\
\text { literary works. }\end{array}$ & 77,5 \\
62 & $\begin{array}{l}\text { I try to write after reading literary works. } \\
63\end{array}$ & $\begin{array}{l}\text { I became fond of writing because I read } \\
\text { a lot. }\end{array}$ \\
60 & $\begin{array}{l}\text { I am motivated to write because I read } \\
\text { a lot. }\end{array}$ & 74,6 \\
61 & I can produce a literary work. & 59,2 \\
\hline
\end{tabular}

\section{Learning Outcomes Understanding Poetry in} Experimental Class I and II

The results of the first hypothesis testing show that there is no significant difference in learning outcomes to understand poetry using cooperative learning model type STAD and CIRC. This is evidenced by the results of the data analysis obtained t-test $=0.678$ and $t$ table value $=1.67$. This means $\mathrm{t}$-test $<\mathrm{t}$ table, so $\mathrm{H} 1$ is rejected and $\mathrm{H} 0$ is accepted. In addition, the acquisition of the average score of the learning 
outcomes to understand poetry was not much different after being taught by STAD type cooperative learning model in experimental class I and CIRC cooperative learning model in Experiment II class. The average score of students studying with STAD type cooperative learning model is 75.48. The average score of students studying with CIRC type cooperative learning model is 73.50 . The average difference between the two experimental classes is 1.98. The result of learning to understand poetry using STAD type cooperative learning model is 1.98 is superior compared with the result of learning to understand poetry using cooperative learning model of CIRC type. Differences in learning outcomes to understand the poetry with both types of cooperative learning model are not too large. This proves that the two types of cooperative learning model are equally effective to be used in the process of learning to understand poetry.

In addition, when compared with test results before students studying with cooperative learning model type STAD and CIRC, student learning outcomes change. Student learning outcomes have increased. The average score of students before learning with STAD type cooperative learning model is 39.6 and after learning with STAD type cooperative learning model is 75,48 . Differences in student learning outcomes before and after learning with STAD type cooperative learning model is 38.88 . The average value of students before learning with CIRC type cooperative learning model is 38.85 and after learning with cooperative learning model CIRC type is 73.50. Differences in student learning outcomes before and after learning with cooperative learning model CIRC type is 34.65 .

The application of cooperative learning model type STAD and CIRC give positive influence to the result of learning to understand poetry. Learning outcomes after using both models are not much different because they are both effective use in the learning process. Students are more motivated in the learning process, students who initially have difficulty understanding the inner structure and physical structure of poetry become more familiar with the concepts.

\section{Learning Outcomes Understanding Poetry with High Literary Reading Interest in Experimental I and II classes}

The result of the second hypothesis test shows that there is no significant difference in the result of learning to understand the poetry of students with the high literary reading interest who learning by using STAD type cooperative learning model and students with high literary reading interest learning with cooperative learning model of CIRC type. This is evidenced by the results of the obtained t-test $=0.039$ and $t$ table value $=1.71$. This means $\mathrm{t}$-test $<\mathrm{t}$ table, so $\mathrm{H} 1$ is rejected and $\mathrm{H} 0$ is accepted. In addition, the acquisition of the average score of the learning outcomes to understand student poems was not much different after being taught by STAD type cooperative learning model in experimental class I and CIRC cooperative learning model in experiment II class.

The average score of students in learning with STAD type cooperative learning model is 75.65. The average score of students in learning with CIRC type cooperative learning model is 75.05. The average difference between the two experimental classes is 0.6 . The results of learning to understand the poetry of students with high literary reading interest learning with STAD type cooperative learning model is 0.6 is superior compared with the results of learning to understand the poetry of students with the high literary reading interest learning model with cooperative learning type CIRC. Differences in learning outcomes to understand the poetry of students with the high literacy reading interest in learning with both types of cooperative learning model are not too large. This proves that both types of cooperative learning model are equally effective in using the learning process to understand the poetry of students with high literary reading interest.

In addition, when compared with test results before students with high literacy reading interest with cooperative learning model type STAD and CIRC student learning outcomes changed. Student learning outcomes have increased. The average score of students with high literacy interest before learning with STAD type cooperative learning model is 39.39 and after learning with STAD type cooperative learning model is 75,65. Differences in student learning outcomes before and after learning 
with STAD type cooperative learning model is 36.26. The average score of students with high literacy interest before learning with CIRC type cooperative learning model is 39.5 and after learning with cooperative learning model CIRC type is 75,5. Differences in student learning outcomes before and after learning with cooperative learning model CIRC type is 36 .

\section{Learning Outcomes Understanding Poetry with Low Literary Reading Interest in Experimental I and II classes}

The result of the third hypothesis testing shows that there is no significant difference in the result of learning to understand the poetry of the students with low literary reading interest that learn by using STAD type cooperative learning model and the students studying with low literary reading interest that learn by using CIRC type cooperative learning model. This is evidenced by the results of t-test $=0.723$ and $t$ table value $=1.70$. This means $\mathrm{t}$-test $<\mathrm{t}$ table, so $\mathrm{H} 1$ is rejected and $\mathrm{H} 0$ is accepted. In addition, the acquisition of the average score of the learning outcomes to understand student poems was not much different after being taught by STAD type cooperative learning model in experimental class I and CIRC cooperative learning model in experiment II class.

The average scores of students with the low literary reading interest in learning with STAD type cooperative learning model are 75.95. The average scores of students are 73.05. The average difference between the two experimental classes is 2.9. The results of learning to understand the poetry of students with the low literary reading interest in learning with STAD type cooperative learning model is 2.9 superior compared with the results of learning to understand the poetry of students with low literary reading interest learning with cooperative learning model type CIRC. Differences in learning outcomes to understand the poetry of students with low literary reading interest who learn with both types of cooperative learning model are not too large. This proves that both types of cooperative learning model are equally effective to be used in the learning process.

In addition, when compared with the results of tests before students with low literary reading interests learning with cooperative learning model type STAD and CIRC student learning outcomes changed. Student learning outcomes have increased. The average score of students with low literary reading interest before learning with STAD type cooperative learning model was 39.54 and after learning with STAD type cooperative learning model was 75.95. Differences in student learning outcomes before and after learning with STAD type cooperative learning model is 36.41 . The average score of students with low literary reading interest before learning with CIRC type cooperative learning model is 38.89 and after learning with cooperative learning model CIRC type is 73,05. Differences in student learning outcomes before and after learning with cooperative learning model type CIRC is 34.16 .

\section{The Interaction between Cooperative Learning Model Type STAD and CIRC with Literary Reading Interest in Influencing Learning Outcomes Understanding Poetry}

An interaction occurs when the effects of one factor depend on another factor in influencing something. The result of the fourth hypothesis test shows that there is no interaction between the two learning models and the literary reading interest in influencing the result of learning to understand poetry. This is evidenced by the results of the hypothesis test obtained F-test $=$ 0.203 and $\mathrm{F}$ table $=4.02$. This means $\mathrm{F}$-test $<\mathrm{F}$ table, so $\mathrm{H} 1$ is rejected and $\mathrm{H} 0$ is accepted. This means there is no interaction between the learning model with the literary interest in influencing the learning outcomes to understand poetry.

STAD and CIRC cooperative learning models are not dependent on one another with the literary reading interest in influencing learning outcomes to understand poetry. This means that without the literary reading interest, cooperative learning model type STAD and CIRC will still affect the results of learning to understand poetry. Conversely, without the cooperative learning model of STAD and CIRC type, literary reading interest will still influence the learning outcomes of understanding poetry. Furthermore, students who have high literary reading interest and low literary reading interest can learn by using cooperative learning model type STAD and CIRC. 


\section{Discussion}

The results of the questionnaire analysis showed that students involved in the learning process had different literary reading interest backgrounds, some were high and some were low. They are spread across two different experimental classes. In the learning process, the teacher has the task to help students improve reading skills and instil reading habits to students. The method that can be used by the teacher is to provide time to read, offer reading choices to students, share reading material to friends, and provide models of adult reading that are appropriate for them (Moser \& Morrison, 1998). The learning process is done by reading and writing, reading and writing again. The composition of reading and writing is a method that can have an influence on increasing the interest and motivation of students reading. Students will be actively involved in learning and have good reading attitudes and habits (Moser \& Morrison, 1998). The method applied is in accordance with the principles of the CIRC type of cooperative learning. This method can increase students' interest and motivation in reading. If students have a great interest in reading, then they will be able to understand all types of texts for any purpose (O'Flynn, 2016), including understanding poetry texts.

Student learning outcomes indicate that the STAD and CIRC cooperative learning models can be used in the learning process of understanding poetry, both students with the high literary reading interest and the low literary reading interest. Thus, learning can be carried out without having to consider the high and the low literary reading interest because cooperative learning can improve reading motivation (Shaaban et al., 2007). Students who have the high literary reading interest will increase their learning outcomes and students who have the low literary reading interest will be motivated to improve the quality of their learning. In addition to interest factors, learning carried out in cooperative groups is also a major factor in increasing learning outcomes in understanding poetry. Student interaction in groups is also influenced by group composition and student personality (Webb, 1984). In addition, the choice of the right learning strategy or model has an effect on improving the student's reading experience (Suryaman, 2018).
Heterogeneous group division has an influence on student learning outcomes. All this time group learning is considered boring for students because only smart students work while others don't. The division of groups carried out by students sometimes creates discrimination among students. students will choose a group of friends who feel close to them so that there is a striking difference between students. Good collaboration between students is not created because there are those who feel marginalized. The heterogeneous group divided by the teacher reduces discrimination between these students. The teacher can divide the group by paying attention to the various backgrounds of students' abilities. Students who have high abilities can work together to help friends who have low abilities (Ramadhanti, 2017:41).

In addition, in the process of doing tests, the experience of learning in groups is a motivation for students to understand poetry. this shows that individual accountability increases with teamwork (Slavin \& Tanner, 1979). In addition to the interest factor and cooperative group division, the strategy used by the teacher in managing cooperative learning in the classroom is an important factor in the implementation of the learning process. By using poetry text as a medium in the learning process, the teacher has implemented text-based cooperative learning. The cooperative learning process, especially the STAD type can also be implemented by teachers together with Web-based technology (Hariadi, 2015). Thus, the teacher becomes a determining factor in the implementation of the cooperative learning process in the classroom. The teacher's experience in implementing previous learning and the learning context in the form of groups requires the teacher to continue to guide students in the problem-solving process in accordance with the material being studied (Siegel, 2005).

Teachers who apply cooperative learning in the classroom make learning more mediated. With teachers implementing group work to make the class more disciplined, students also showed a positive interaction in their group (R. M. Gillies, 2006). Teachings mediated by teacher interaction have sparked hope in students who are sensitive to their need to provide more detailed explanations and responses to others. The interaction between teachers and students in cooperative groups occurs because students 
understand how to negotiate group tasks. When teachers build cooperative learning in the classroom, they create well-structured groups and influence the way they interact in groups (Gillies, 2008). Student verbal behaviour in groups helps and supports group work. Students listen earnestly what the teacher says and do the job well. Student verbal behaviour arises because they are challenged to think deeper and clearer about the issues being discussed. Students are required to reflect on the implications of each poem he read and conclude the physical structure and inner structure of poetry.

\section{CONCLUSION}

Cooperative learning is the way to improve the high-level thinking skills needed in the 21 st century. Students who are able to develop teamwork in study groups will be increasingly encouraged in the process of thinking in solving problems in accordance with the subject matter. Student interaction in groups affected by group composition strongly affects the accountability of each individual in performing the task, especially understanding poetry. STAD and CIRC's cooperative learning enhances students' understanding of the physical structure and inner structures of poetry requiring critical reading skills. Students with low reading interest are motivated in learning because cooperative learning can encourage students to think and read.

\section{ACKNOWLEDGEMENT}

Our thanks go out to the parties as follows. First, for the Kementerian Riset, Teknologi, dan Pendidikan Tinggi (Kemenristek Dikti) in accordance with the Assignment Agreement Implementation Research Program No. SP DIPA-042.06.1.401516/ 2017 dated December 06,2016 , which was fully prepared to fund this research. Second, the student at Program Studi Pendidikan Bahasa dan Sastra Indonesia in STKIP PGRI Sumatera Barat which was ready to be samples of this research. Third, the leader of Unit Penelitian dan Pengabdian pada Masyarakat (UP3M) STKIP PGRI Sumatera Barat. Fourth, the editorial team of Jurnal Cakrawala Pendidikan who has been willing to publish this article.

\section{REFERENCES}

Adesoji, F. a., \& Ibraheem, T. L. (2009). Effects of Student Teams-Achievement Divisions Strategy and Mathematics Knowledge on Learning Outcomes in Chemical Kinetics. The Journal of International Social Research, 2(6), 15-25.

Bromley, K., \& Modlo, M. (1997). Using Cooperative Learning To Improve Reading and Writing in Language Arts. Reading \& Writing Quarterly, 13(1), 21-35. https:// doi.org/10.1080/1057356970130103

Durukan, E. (2011). Effects of cooperative integrated reading and composition (CIRC) technique on reading-writing skills. Educational Research and Reviews, 6(1), 102-109. Retrieved from http://www.academicjournals.org/article/ article1379666882_Durukan.pdf

Gillies, R., Ashman, A., \& Terwel, J. (2008). The teacher's role in implementing cooperative learning in the classroom. Science Education. https://doi.org/10.1007/978-0387-70892-8

Gillies, R. M. (2006). Teachers' and students' verbal behaviours during cooperative and small-group learning. British Journal of Educational Psychology, 76(2), 271-287. https://doi. org/10.1348/000709905X52337

Hariadi, B. (2015). Web-Based Cooperative Learning, Learning Styles, and Student'S Learning Outcomes. Cakrawala Pendidikan, 53(ii), 1689-1699. https://doi. org/10.1017/CBO9781107415324.004

Khairuddin, Z. (2013). A Study of Students' Reading Interests in a Second Language. International Education Studies, 6(11), 161-170. https://doi.org/10.5539/ies. v6n11p160

Moser, G. P., \& Morrison, T. G. (1998). Reading Horizons Increasing Students' Achievement and Interest in Reading Increasing Students' Achievement 
and Interest in Reading. The Berkeley Electronic Press, 38(4), 15.

O’Flynn, K. (2016). Students ' Reading Interests Impact on Reading Comprehension Abilities Students, Reading Interests Impact on Reading Comprehension Abilities. Education Master, 1-71. Retrieved from https://fisherpub.sjfc.edu/ cgi/viewcontent.cgi?referer=https://www. google.co.id/\&httpsredir $=1 \&$ article $=1330$ \&context=education_ETD_masters

Ramadhanti, D \& Diyan PY. (2017). Memahami Puisi. Yogyakarta: Deepublish.

Ramadhanti, D. (2017). Penerapan Model KooperatifTipe CIRC dalam Pembelajaran Menulis Narasi Siswa Kelas VII SMP Negeri 2 Lembah Gumanti. Gramatika, 3(1), 27-42. https://doi.org/http://dx.doi. org/10.22202/JG.2017.V3i1.1230

Sachs, G. T., Shum, S., Bureau, M., Kong, H., \& Christopher, N. (2003). Developing Cooperative Learning the ELF/ESL Secondary Classroom. Regional Language Centre Journal, 34(3), 338-369.

Shaaban, K., Al-Badawi, G., \& Ghaith, G. (2007). Erratum: An initial study of the effects of cooperative learning on reading comprehension, vocabulary acquisition, and motivation to read (Reading Psychology (2006) 27, 5 (377-403). Reading Psychology, 28(1), 131. https:// doi.org/10.1080/02702710601071518

Slameto. (2010). Belajar dan Faktor-Faktor yang Mempengaruhi. Jakarta: Rineka Cipta.

Siegel, C. (2005). Implementing a ResearchBased Model of Cooperative Learning. Journal of Educational Research, 98(6), 339-349. https://doi.org/10.3200/ JOER.98.6.339-349
Slavin, R. E., \& Tanner, A. M. (1979). Effects of cooperative reward structures and individual accountability on productivity and learning. Journal of Educational Research, 72(5), 294-298. https://doi.org /10.1080/00220671.1979.10885175

Slavin, R. (1994). Cooperative learning: Theory, research and practice (2nd ed.). Boston: Allyn and Bacon.

Stevens, Robert J. (2008). Cooperative Learning and Literacy Instruction in Middle Level Education. In R. M. Gillies, A. F. Ashman, J. Terwel (Eds). The Teachers' Role in Implementing Cooperative Learning in the Classroom. (92-109). Heidelberg: Springer.

Suryaman, M. (2018). Pengalaman Membaca Karya Sastra dalam Perspektif Pembelajaran. Litera, 17(1), 120-134. https://doi.org/http://dx.doi.org/10.21831/ ltr.v17i1.19063

Suyitno, Andayani, \& Nugraheni. (2015). Pembelajaran Berbasis Pendidikan Karakter Berbahan Ajar Puisi dengan Teknik Pembacaan HeuristikHermeneutik. Litera, 14(1), 122-133. https://doi.org/http://dx.doi.org/10.21831/ ltr.v14i1.4412

Tiantong, M., \& Teemuangsai, S. (2013). Student team achievement divisions (STAD) technique through the moodle to enhance learning achievement. International Education Studies, 6(4), 85-92. https:// doi.org/10.5539/ies.v6n4p85

Webb, N. M. (1984). Sex differences in interaction and achievement in cooperative small groups. Journal of Educational Psychology, 76(1), 33-44. https://doi. org/10.1037/0022-0663.76.1.33 